\title{
EMPIRICAL ANALYSIS OF FEMALE PARTICIPATION IN EDUCATION, PARLIAMENTS, AND WORKFORCE ON ECONOMIC DEVELOPMENT IN MUSLIM COUNTRIES
}

\author{
Nurul Hasanah \\ Politeknik Negeri Jakarta \\ Jurusan Akuntasi, Program Studi Keuangan dan Perbankan Syariah \\ e-mail: nurul.hasanah@akuntansi.pnj.ac.id \\ Ira Eka Pratiwi \\ IAIN Fattahul Muluk Papua, Fakultas Ekonomi dan Bisnis Islam \\ e-mail: iraeka.pratiwi@iainpapua.ac.id
}

\begin{abstract}
The main objective of this study is to investigate female participation on education, parliament, and workforce in Muslim countries. By using secondary data over the period from 2010 until 2014 and parametric analysis, it can be concluded that there is a significant difference between female participation in Middle East and non-Middle East countries. The estimation showed that the average of female in parliament and female labor force participation are higher in non-Middle East countries. Furthermore, the study also estimates the influence of female participation on economic growth. By using multiple regression panel data method, processed by E-Views, the result found that both female literacy rate and female participation in parliament have a positive and significant relationship with economic growth in Muslim countries. Meanwhile, the result of female labor force participation and female unemployment rate show insignificant effect on economic growth.
\end{abstract}

Keywords: Muslim Countries, Female, Literacy, Labor Force, Unemployment, Economic Growth.

\section{INTRODUCTION}

When compared to non-Muslim countries, then most of the Muslim countries in the world are lagging behind. Kuran (1997, p.41) mentions, "The world's predominantly Muslim countries have long been underdeveloped. Few will deny that the level of economic development has long been lower in the Islamic world than in West." Meanwhile Ebrahim, Makhdoomu, and Sheikh (2012, p.2) state that according to some analysts, the underdevelopment in Muslim world is not caused by external factors or western imperialism. It was due to internal factors which related to religion, society and politics. Kuran (1997) on his observation based on his reading literature about what scholars explain facing the underdevelopment in Muslim countries put Islam itself as a permanent barrier to development. (Ahmad, Bhatti, and Arshad, 2013, p.74). However, 
rather than blaming Islam itself as the impediment to growth, there are some others thinkers argue that there are other factors that cause the prolonged underdevelopment in Muslim countries.

Lewis (2002) explains about what went wrong in the Islamic world is because there are large part in Muslim world to the relegation of females to an inferior position in society, thereby depriving the Islamic world of the talents and energies of half its people.

The role of women in economic development has been a popular topic in academic and policy debates (ADB, 2016). One of the reasons is refer to the fifth targets of Sustainable Development Goals (SDG), a development framework of countries in the world, achieve gender quality and empower all women and girls. The equality and empower women are considered to be important because women and development have a reciprocal relationship. On the one hand, economic growth can affect the gender inequality. On the other hand, gender inequality has an influence on development.

Some studies agree that by issuing investment to improve the quality of women, then this will have an impact on economic growth. Unfortunately, women still face many obstacles to participate in the development. In most countries, women have less opportunity to contribute in the development. In some sector such as education, health, workforce, and politics, women are still experiencing inequality.

According to World Bank (2016), female still face discrepancy in primary and secondary completion particularly in middle income countries and low income countries. Despite steadily increased from 1991 to 2013, female primary completion is still less than male. In the workforce, women also experience gap with men. Even in high income countries, women are less likely to participate than men in the labor market. Dramatically, women are more likely to work without pay than men.

Education is actually plays an important factor related to female participation in society. Educated female more appreciated and have the opportunity to gain the inferior position in the community and society. They can act as professionals, teachers, farmers entrepreneurs, and politicians where it can have the potential to boost the economy. Female education plays at least three important role in influencing the economic. First is human capital. If more female are allowed to go to school, leading to the overall improvement of human capital and positive impacts on economic growth. Since, it is a part of human capital investment which is has a significant effect on growth (Dollar and Gatti 1999). Second role of female education is to keep the longevity of next generation. Some studies have been proved that educated women well prepared in their children education and health. And, thus can affect the economic growth. And the third is the effect of female education to their income. Educated women tend to be easier to get a job. The higher the education, the jobs are obtained will also be good. In addition, this will also affect the income earned.

Five regions in the world; Asia-Pasific, Middle East and North Africa (MENA), Sub Saharan Africa, Europe and Euro-Asia, and America, consists of a total Muslim population of 2,038 billion people in 2014 , which roughly 50 per cent of the world's 
population is females or approximately 1,016 billion people. ${ }^{1}$ It could open the opportunity for Muslim world to build their economic. Some studies predict that for 20 to 30 years into the future, countries with the highest population in the world will experience significant economic growth and are in the top $10^{\text {th }}$ position. According to The Wealth Report $(2012)^{2}$, by 2050 some of Muslim countries with numerous population are predicted to be the top tenth of the world's largest economic. India is expected to be in the first rank with GDP of $\$ 85.97$ trillion. Meanwhile, Indonesia is forecasted to be in the forth rank accompanied with Nigeria in sixth position and Egypt in tenth. The forecasting also highlights the top $10^{\text {th }}$ countries with high rates of economic growth from 2010 until 2050 in which most of them are Muslim countries that are categorized as developing countries such as Nigeria $\left(1^{\text {st }}\right)$, India $\left(2^{\text {nd }}\right)$, Iraq $\left(3^{\text {th }}\right)$ Bangladesh $\left(4^{\text {th }}\right)$, Indonesia $\left(5^{\text {th }}\right)$, and Egypt $\left(6^{\text {th }}\right)$.

However, different cultures among Muslim countries make the perception of women's role in economic development is also different. In politics, for example, women in a number of countries in the Middle East is still restricted to engage in the political arena. Besides because of the religious interpretations that conservatives, it's also because of family dimension needs to be considered that still makes women are traditionally responsible for household duties (Al-Tal'ei, 2007). Cultural perception also limits the opportunity for women to access the job even occupy the professional positions. Although governments in the Middle East has created policies and increase the number of women workers but this cultural view causes a woman is deemed not capable, more irrational and better suited for family responsibility (Kelly, ). Moreover, in the world of education is also there are still gap between women and men in the middle east. Males tend to be more literate than the women. Again, this was due to the culture and the way the different views between the middle east region with countries outside the Middle East.

This study is trying to explore the difference of female participation between Muslim countries in Middle East and non-Middle East and also to examine the influence of factors related to the quality of women such as women's participation in workforce, women's education, and political participation of women on economic growth of the Muslim countries. With bonus demography rarely owed by west countries, we believe that Muslim country still have a great chance to improve their economy by empowering women and paying attention to significant factors related to quality improvement.

\section{Problem Statement}

The study aims to examine the role and contribution of Muslim female in their countries for the economic development in Islamic world. Therefore, the formulation of the problem can be decomposed by the following question:

1) What is the difference between female participation in Muslim countries particularly in Middle East and non-Middle East?

\footnotetext{
${ }^{1}$ http://www.muslimpopulation.com/World/

${ }^{2}$ http://www.knightfrank.com/wealthreport
} 
2) What are the significant variables have to be concerned with respect to the female's role that can influence their contribution to the economic growth in Islamic world?

\section{Research Objectives}

This research is conducted to achieve these following objectives, namely:

1) To analyze the difference of female adult literacy, female labor force participation, female unemployment, and female in parliament in Muslim countries particularly

2) To determine the influence of the following variables with respect to the female's role to the economic growth in Muslim majority countries, specifically:

- To determine the influence of female's labor force participation rate in Muslim majority countries on the economic growth.

- To determine the influence of female's participation in parliament in Muslim majority countries on the economic growth.

- To determine the influence of female's unemployment in Muslim majority on the economic growth.

- To determine the influence of female knowledge and education in Muslim majority countries as measured by female literacy rate, on the economic growth.

\section{LITERATURE REVIEW}

\section{Islam and Female}

Islam was revealed to overturn the social facts that occurred in the time of ignorance, one is overcome social inequality among women. According to Yusuf alQhardhawi, Islam was revealed at a time when a lot of people denied the humanity of the female. With the advent of Islam, circumstances improve for the female. The female's dignity and humanity were restored.

In Islam, the status of women and men are equal, whereas that sets it apart is the level of piety to God. Allah says, "And whoever does righteous deeds, whether male or female, while being a believer - those will enter Paradise and will not be wronged, [even as much as] the speck on a date seed." (QS. An-Nisa: 124)

According to Al Khayat (2003), "Islam establishes complete and genuine equality between male and female. This is a fact readily acknowledged by everyone who knows Islam well and understands Islamic law as outlined in God's book, the Qur'an, and in the sayings and practices of the Prophet Muhammad." He added that under Islam, male and female have no different rights and change in every aspect of life including to take up any profession and equal wages for the same work. During the lifetime of the Prophet, female can work in every area such as agriculture, some tended animals, or worked in weaving and cloth making, or in home industries, or other trades. Some females were nurses caring for those who were ill or tending men injured in battle. Also, Islam assigns equal political responsibility to both man and female with regard to maintaining proper order in society. 
But this does not mean that with the equal opportunity to work then it becomes an obligatory for women. In Islam, work for a woman is a choice. Female may undertake it whenever circumstances allow. However, for men, work is an obligation. Allah says, "Men are in charge of women by [right of] what Allah has given one over the other and what they spend [for maintenance] from their wealth. (Q.S An-Nisa:34)" Furthermore, Islam gives both man and female equal rights, or indeed it makes them equally dutybound, to acquire knowledge. The Prophet is quoted as saying: "Seeking knowledge is a duty incumbent on every Muslim (man or female)." "3 This constitutes a practical Islamic requirement that illiteracy must be erased completely for both sexes.

\section{Female and Development}

While some of thinkers found that Islam is the cause of the deterioration in the economic development of the Muslim world, but some other say precisely that Islam strongly supports economic development. When viewed from the historical development of Islam since the time of the Prophet rule until the reign of the caliph, it can be seen that Islam is one of the factors bearer of economic progress in his days. This is seen in the caliphate of Omar Ibn Abdul Aziz in the Umayyad dynasty (99-101 AH / 717-719 AD), which experienced the glories of Islam and its people were prosperous. Huda (2012, p.178) wrote that the state actually had a surplus, even rose to the level where personal debt and the cost of marriages are also borne by the state. In addition, one of the indicators of prosperity that existed at that time is when the Amil Zakat around in the African village, but they did not find someone else who is entitled to receive zakat. That is, at the moment there are no poor people.

Noland (2003, p.43) concludes that there is no prove that Islam is the inimical for growth. It is argued that Islam positively promotes growth and economic development. On his research, Nolad investigated the relationship between religion, culture, and economic performance in India, Malaysia, and Ghana. The result of the study show, in both cross-country and within-country statistical analyses, the relationship between Islamic religion, Muslim population, and economic growth in these countries is positive and statistically significant, in the sense that Islam is not an impediment of the economic development.

According to Ibn Khaldun's theory of Development (Chapra, 2006, p.12), the trigger mechanism of Muslim decline was the failure of the political authority which consecutively in most Muslim countries until the present time, and has led to the misuse of public resource and their non availability for realization of justice, development and general well-being. In summary, Chapra state the Ibn Khaldun's analysis by forming a functional relationship, as follow:

$$
G=f(S, N, W, j \text { and } g)
$$

In this equation, Chapra expresses that $G$ or the political authority is a function of the $S$ or the implementation of the Shariah, $N$ or well-being of the people, $W$ or state wealth,

\footnotetext{
${ }^{3}$ Related by Ibn Majah and others on the authority of Anas Ibn Malik.
} 
$j$ or justice, and $g$ or development. If the political authority or $G$ is corrupt and incompetent and not accountable before people or $N$, means that the government did not implement the shariah $(S)$ function, it will not perform its function conscientiously. Therefore, the state wealth $(W)$ will not effectively be utilized and the services that need to be provided to facilitate development will not become available. There will be no justice $(j)$ for the well-being $(N)$ and the development $(g)$. Furthermore, Chapra also explains that Ibn Khaldun's theory concerned about the lack of the government authority as the main factor of Muslim countries decline, so the function puts $G$ or political authority as the dependent variable and the others as independent variables. However, the relationship between all variables generally tends to be circular and interdependent causation. Any one of the independent variables may be treated as a dependent variable with the others being considered independent. Chapra explains that the trigger mechanism could also be the decline in the quality of human beings $(N)$, which related with the main theme of this paper. Specifically, Chapra mentions that the position of females as human indicator $(\mathrm{N})$ in the equation with respect to the development improved significantly according to some scholar's studies.

One thing to realize is that women are part of this planet. Their presence in the community could not be ignored, especially their role in the development and sustainability of the planet. Actually, particularly in Muslim world, or generally in the world, women constitute is about half of the population (Genc, AbuAl-Foul, and Azkul, 2012). According to the World Bank data, female population average in 50 Islamic majority countries is about 48 per cent. Or, it can be said that male and female population particularly in Muslim majority countries is approximately one-to-one. Therefore, female should play an important role for economic development in a country as well as male. Christiaan Poortman, World Bank Vice President for the Middle East and North Africa, states that: "No country can raise the standard of living and improve the well-being of its people without the participation of half its population. Experience in other countries has shown over and over again that women are important actors in development - to hold them back is to hold back the potential for economic growth."

\section{Female Quality Factor Evidence in Macro-Level}

According to World Bank, GDP per capita is gross domestic product divided by midyear population. GDP is the sum of gross value added by all resident producers in the economy plus any product taxes and minus any subsidies not included in the value of the products. Data from Wolrd Bank show that Qatar is the country with highest GDP per capita, following United Emirates Arab (UEA), Saudi Arabia, and Oman which is known as OPEC countries.

Meanwhile, there are still about 14 countries out of 50 countries from 2010 to 2014 had per capita income of US \$ 975 or less and classified as low-income countries. Egypt is becoming one of the low-income countries due to political turmoil in 2014 and the resulting drop in state revenue from 2010 to 2014. Meanwhile, most of the Islamic 
countries in Asia and Europe at the level of middle-income countries vary between middle income lower and upper middle income countries.

Meanwhile, the highest rate of female labor force participation is experienced by Sub Saharan Africa countries, such as Mozambique, Eritrea, Ethiopia, Burkina Faso, Gambia, Senegal, Guinea, and Sierra Leone as shown in graphic 1.2.

According to Chen (2008) Sub-Saharan Africa is known as a region in Africa which have high rate of female labor force participation and most of them are working in informal sector primarily in agriculture sector. Unfortunately, women tend to be distinguished than men. CTA Policy Brief (2012) writes that many women work as parttimer, seasonal basis, or family worker but unpaid. Other than that, they also tend to be paid more less than men, even both of them are in the same position or comparable levels of education and experience. Meanwhile, some countries in Middle East such as Syria, Iraq, Algeria, West Bank and Gaza, Afghanistan, Saudi Arabia, Iran and Jordan have the lowest female labor force participation among other countries. According to Moghadam (2005) several factors such as culture, social policy, and government policy may become the causes that constraints women in participating the paid labor forces. Several researchers have argued that state policies, social policies, labor legislation, and urban infrastructure can be important in explaining the FLFP and a woman's access to paid.

\section{Graphic 1.1 Female Labor Force Participation (Avarage Rate) in Muslim Countries Over the Period 2010 - 2014}

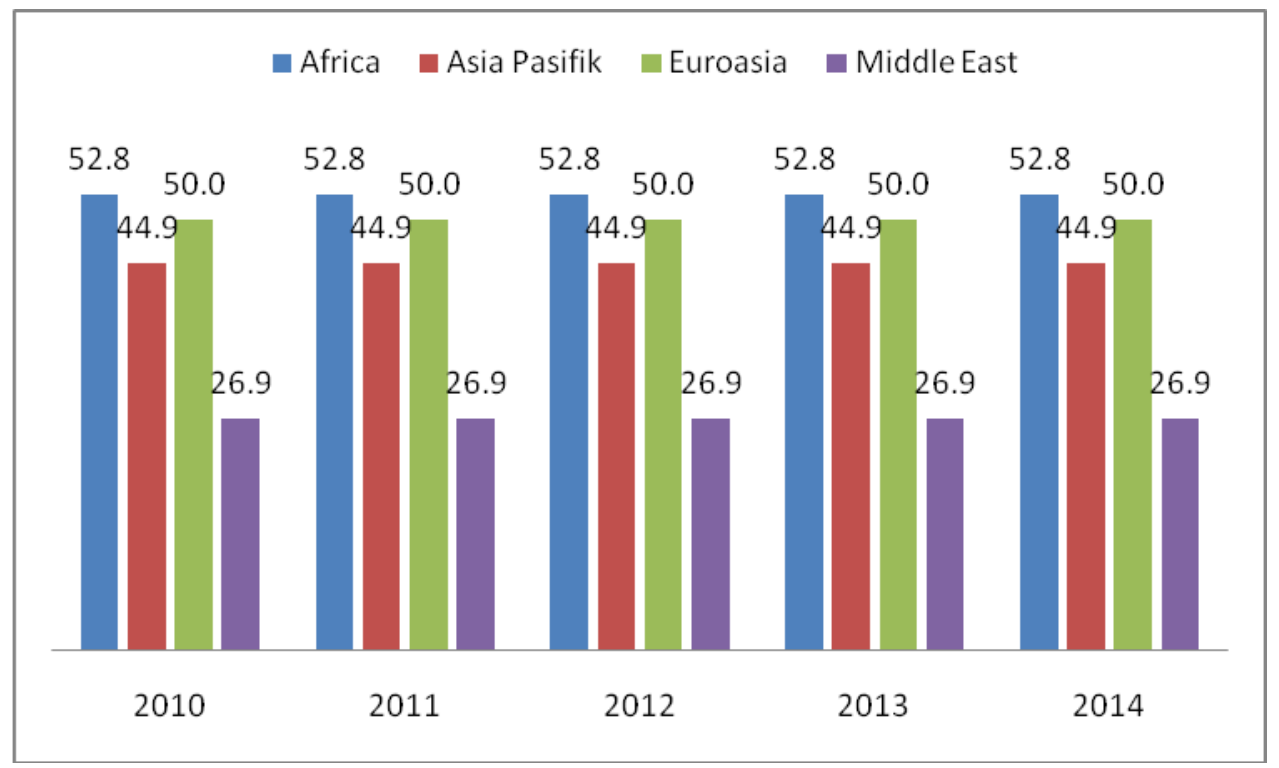

Literacy rate is one of the education indicators. According to $\mathrm{UNESCO}^{4}$, adult literacy or literacy rate is the percentage of population aged 15 years and over who can both read and write with understanding a short simple statement on his/her everyday life.

\footnotetext{
${ }^{4}$ United Nations Educational, Scientific and Cultural Organization (UNESCO) Institute for Statistics, Education Indicator Technical Guidelines, November 2009.
} 
According to the data of World Bank, Euro-Asia countries, such as Tajikistan, Turkmenistan, Uzbekistan, Kyrgyzstan, and south Caucasus, such as Azerbaijan, shards of the Soviet Union, have the highest female (adult 15+) literacy rate. Asylbekov (1993) on Mynbayeva and Pogosian (2014, p.26) concludes that the education since the Soviet period is supported by a strong ideological Communist pressure. The development of education consisted of several stages with the corresponding goals of illiteracy liquidation, the introduction of compulsory secondary public education. The contribution of the Soviet period on education in these countries means a lot to the development of their education. Meanwhile, a large number of countries in Sub-Saharan Africa has the lowest of female (adult 15+) literacy rate. In Sub-Saharan Africa, women experience inequality, especially in the field of education. Johannes (2010) states that the most important disparity in education in Sub-Saharan Africa remains a large problem and one that is difficult to resolve. A lack of teaching supplies, equipment, and especially a lack of teachers make the conditions impossible to provide all children adequate education, especially past the primary school level. In addition, their government does not sufficiently provide funding to insure truly free public schooling. Besides that, longstanding tradition factor that they prefer boys to go to school than girls make the gender gap become wider.

\section{Graphic 1.2 Female Literacy (Avarage Rate) in Muslim Countries Over the Period 2010 - 2014}

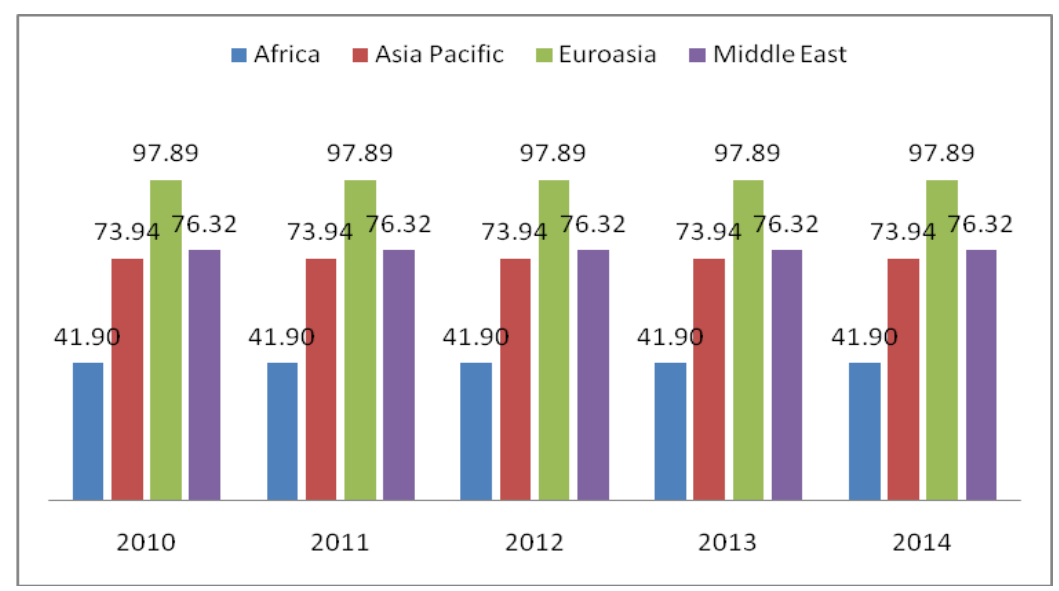

As seen from the data of World Bank, the highest female unemployment rate is dominated by Middle East countries and Africa countries. This means that very few women enter the labor market. It can also be concluded that high rates of unemployment may constrain female labor force participation in those countries. As state by Jelili (2010), the large increase in female labor force participation rates during the last two decades may have contributed to the high rates of unemployment, especially among young females. Social norms might also be an important factor in explaining this unemployment rates. Social norms may limit women mobility to find appropriate jobs. 
Social norms may discourage female from seeking employment elsewhere, while encouraging males.

However, Qatar, a country in the Middle East, has lowest level of female unemployment. In addition because of the population is small, it is also due to the effect of Qatarization where female participation in the labor force increased deliberately to avoid the need for foreign labor (Sayre, Benmansour, Constant, 2015, p.17). Besides that, the thing that pushed women into the workforce is social norms and cultural values. Many of Qatari viewed that working outside the home as something prestigious. Her Highness Sheikha Mozah Bint Nasser Al-Misnad and countless women holding high level positions throughout the workforce become the role models, which there is likely to be increased acceptance and willingness to work outside the home.

\section{Graphic 1.3 Female Unemployment (Avarage Rate) in Muslim Countries Over the Period 2010 - 2014}

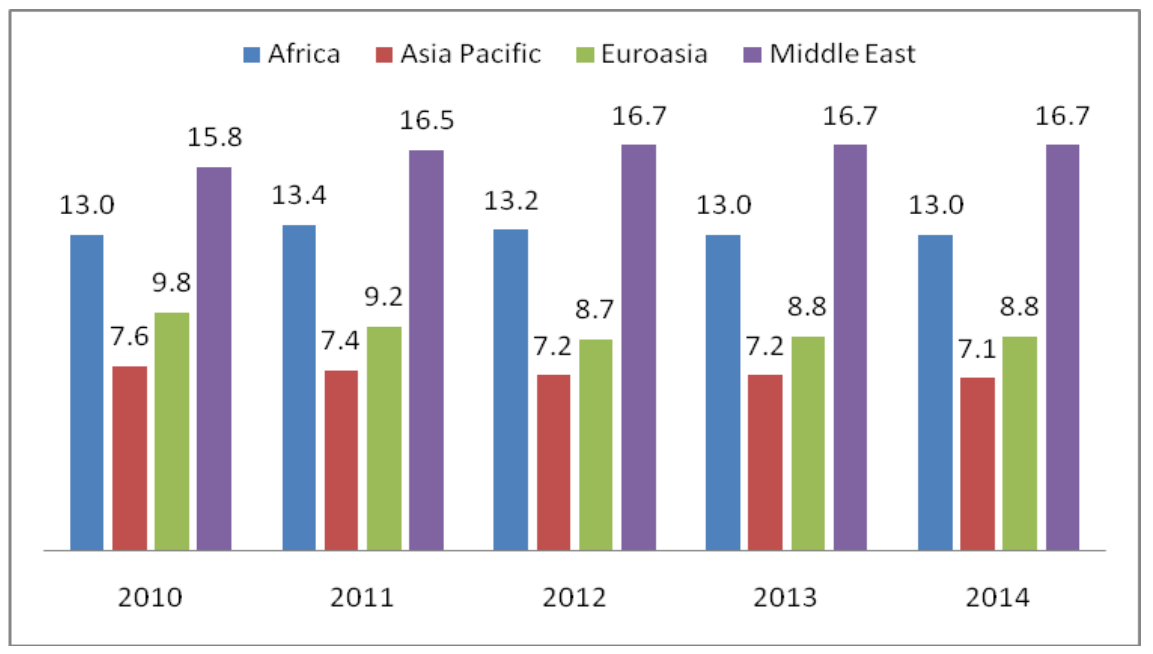

Women in parliament data from the World Bank show that the highest participation of women participation in parliament experienced by some countries in Africa such as Senegal, Mozambique, Tunisia, Algeria, Ethiopia, and Cameroon. Interestingly, the level of women participation in parliament in Algeria fluctuated sharply increased over the past 5 years. In 2010, the portion of women in parliament is 7 percent and this number continue to increase until 2014 with 30 percent. According to Ndlovu and Mutale (2013, p.3), there is no single factor that causes the high participation of women in parliaments in countries in Africa. Several factors like the increase in women's movements, quota systems, multi-party systems, increase in educational opportunities, funding from international institutions, global and national agreements, conventions and commitments amongst others together contribute to this increase.

Instead Egypt is also part of Africa region but dramatically decreased the number of women's participation in parliament. Even in 2013 and 2014, number of women in parliament had no place. Arab countries such as Lebanon, Comoro, Kuwait, Oman, and 
Yemen, also has its share of women in parliament is very low. The political issue and problem contributed in this problem. Meanwhile, Brunei, a country in Southeast Asia, also does not have a quota for women in parliament.

\section{Graphic 1.4 Women in Parliament (Avarage Rate) in Muslim Countries Over the Period 2010 - 2014}

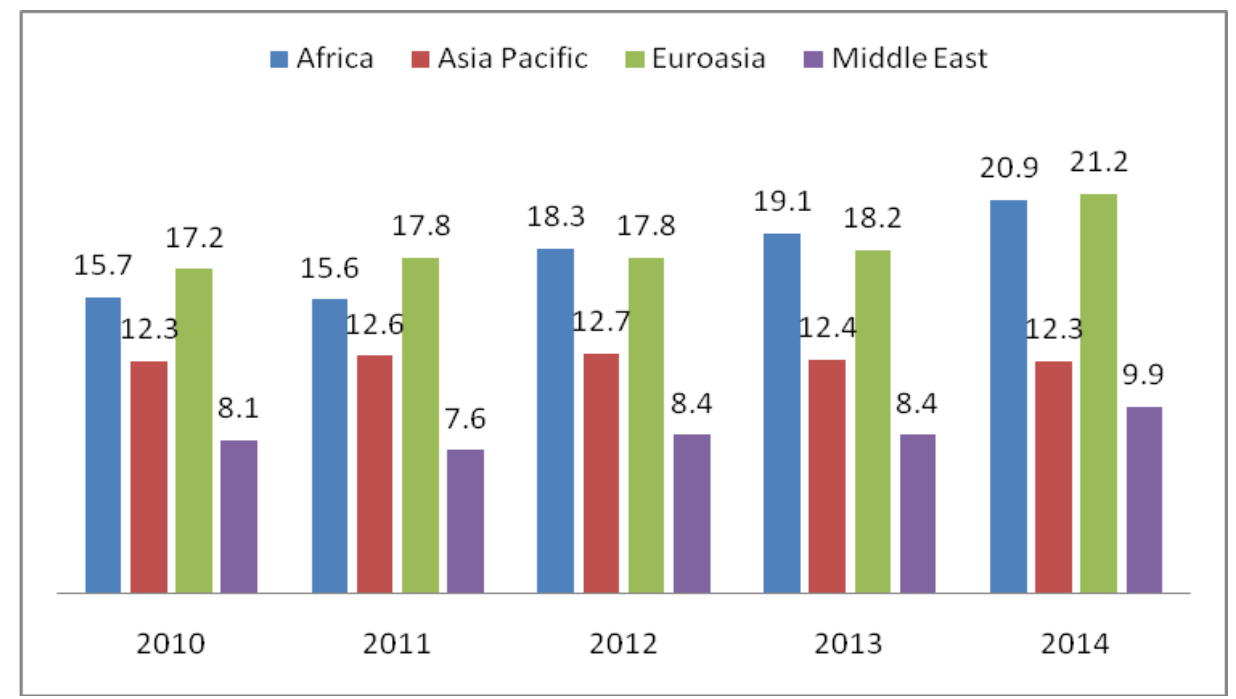

\section{Empirical Evidence}

A number of studies have been conducted to see how female capital such as education, participation in work place, women seats in parliament can impact the economic growth or even reduce the poverty.

\section{Female's Education and Economic Growth}

U.N. Secretary-General, Ban Ki-moon said, "Investing in girls' education will make them productive in life, contribute to society, and make their own family planning decisions."

Oztunc, Oo, and Serin (2015) conducted a research about the long-term effect of female education on economic growth in Asia Pacific region. In this study, Oztunc found that the fertility rate, female labor force participation rate and female primary school enrolment are significant factor for annual per capita income growth. On his study, Oztuch used panel regression analysis to examine the effect of female education by

\footnotetext{
${ }^{5}$ At the January 2012 World Economic, Davos, Switzerland, http://www.un.org/apps/news/story.asp?NewsID=41055\&Cr\&Cr1\#.VyDurojR_IU
} 
focusing on the time period between 1990 and 2010. He collected the data randomly from the selected countries: Bangladesh, Cambodia, China, India, Indonesia, Lao PDR, Malaysia, Myanmar, Philippines, Thailand, and Vietnam.

Another research came from Kalsen and Lamana (2009). They suggest a considerable extent linked to the role played by female in the society for economic growth. They started their research on the impact of gender inequality education and employment on economic growth in different world regions, focusing on Middle East and North Africa (MENA), Sub-Saharan Africa, and South Asia, which tend to have high gender gaps in education and /or employment over the period 1960-2000. By using cross-country and panel regressions, the research found that gender gaps in education and employment considerably reduce economic growth. Gender inequality in labor force participation (as a proxy for gender gaps in employment) and gender inequality in education in MENA and the South Asia have a sizable negative impact on economic growth. It indicates that female has a powerful role in the society for economic development.

\section{Female Labor Force Participation and Economic Growth}

Lechman and Kaur (2015) prove that between economic growth and female labor force had a U-shape relationship. The study conducted investigation about the relationship between female labor force participation and economic growth in 162 countries over the period 1999-2012. The results of this study are first, between economic growth and female labor force confirms a U-shape relationship, although high crosscountry variability remains. Second, the downward slope and the upward slope suggest that there are a negative and positive relationship between female labor force and economic growth. But according to the estimation, it indicates that the negative relationship is dominant and strong, and may be visualized through the downward part of the U-shaped pattern, compared to the positive one. Third, the U-shaped feminization hypothesis was not positively verified in the case of low-income countries. It indicates that still female labor force participation ranges significantly across economies regardless of GDP per capita achieved, and is not solely attributed to economic growth, but preconditioned by a wide array of legal, cultural, social or other unquantifiable factor.

Meanwhile, the study conducted by Lahoti and Swaminathan (2013) found that there is no significant relationship between economic growth and female participation in labor force. Their paper explores the research using state-level employment data particularly in India spanning the last twenty five years, 1983-1984 to 2009-2010. By using dynamic panel models, they suggested that no significant relationship between level of economic development and women's participation rates in the labor force in India. Their results also suggest that growth by itself is not sufficient to increase women's economic activity, but the dynamics of growth matter. These findings are especially important to help design policies to improve women's labor force participation rate so that India can take complete advantage of its upcoming demographic dividend.

Another study conducted by Shahid (2014) who investigated about the relationship between female labor participation and economic growth. His research found that in the 
long run relationship, there is relationship between female labor force and economic growth using Johnson Co-integration test. However, the vector error correction model indicated that economic growth has negative insignificant, gross fixed capital formation positive significant and labor force participation has negative significant relationship in short run.

\section{Female's Participation in Parliament and Economic Growth}

As well as female labor force participation and female education, there is evidence that female participation in parliament also plays an important role in economic development. Jayasuriya and Burke (2012) investigated weather female political representation affects economic growth by using panel estimation from 119 democracies for the period 1970-1990. They then found that both fixed effects and system GMM estimations for a large sample of democracies suggest that, over recent decades, higher representation of females in parliament has led to faster economic growth. The results also provide some evidence that empowering women is an important means toward economic development. Furthermore, Jayasuriya and Burke also mention that countries in the Pacific and the Middle East currently have the lowest shares of females in parliament and therefore likely have the most to gain from improving the gender balances of their parliaments. Meanwhile, Xu (2015) examine the effects of female political participation on economic growth in 30 Asian countries by using cross-country and panel regressions during the period 1991-2013. Xu concluded that in recent years, female political participation fosters economic growth in Asia.

According to Inter-Parliamentary Union, there are primary five major factors that obstruct women to enter politics. The first is domestic responsibilities, second is prevailing cultural attitudes regarding the roles of women in society, third is lack of support from the family, the forth and the fifth are lack of confidence and lack of finance respectively.

In addition, USAID also mentioned that several factors may prevent economic growth in the Islamic world. One of them is the women's inferior position in society and culture. Regarding to this, USAID suggested for enhancing the women's roles such as participation of women in the labor force and in the political process. ${ }^{6}$

As our interest is in the influence of women's role on economic growth for Muslim majority countries, the aforementioned literature has helped to inform the selection of unique explanatory variables for our empirical study.

\section{RESEARCH METHODOLOGY}

\section{Definitions and Source of Variables}

The data used in this study are secondary data from Muslim countries over the year 2010-2014. Meanwhile, the variables consist of following details:

\footnotetext{
${ }^{6}$ USAID Issued Paper PN-ACY-101, Bureau for Policy and Program Coordination, June 2004, Written by Petter Timmer (Development Alternatives, Inc. and Center for Global Development) and Donald McClelland (U.S Agency for International Development, Economic Growth in The Muslim World: How Can USAID Help?
} 


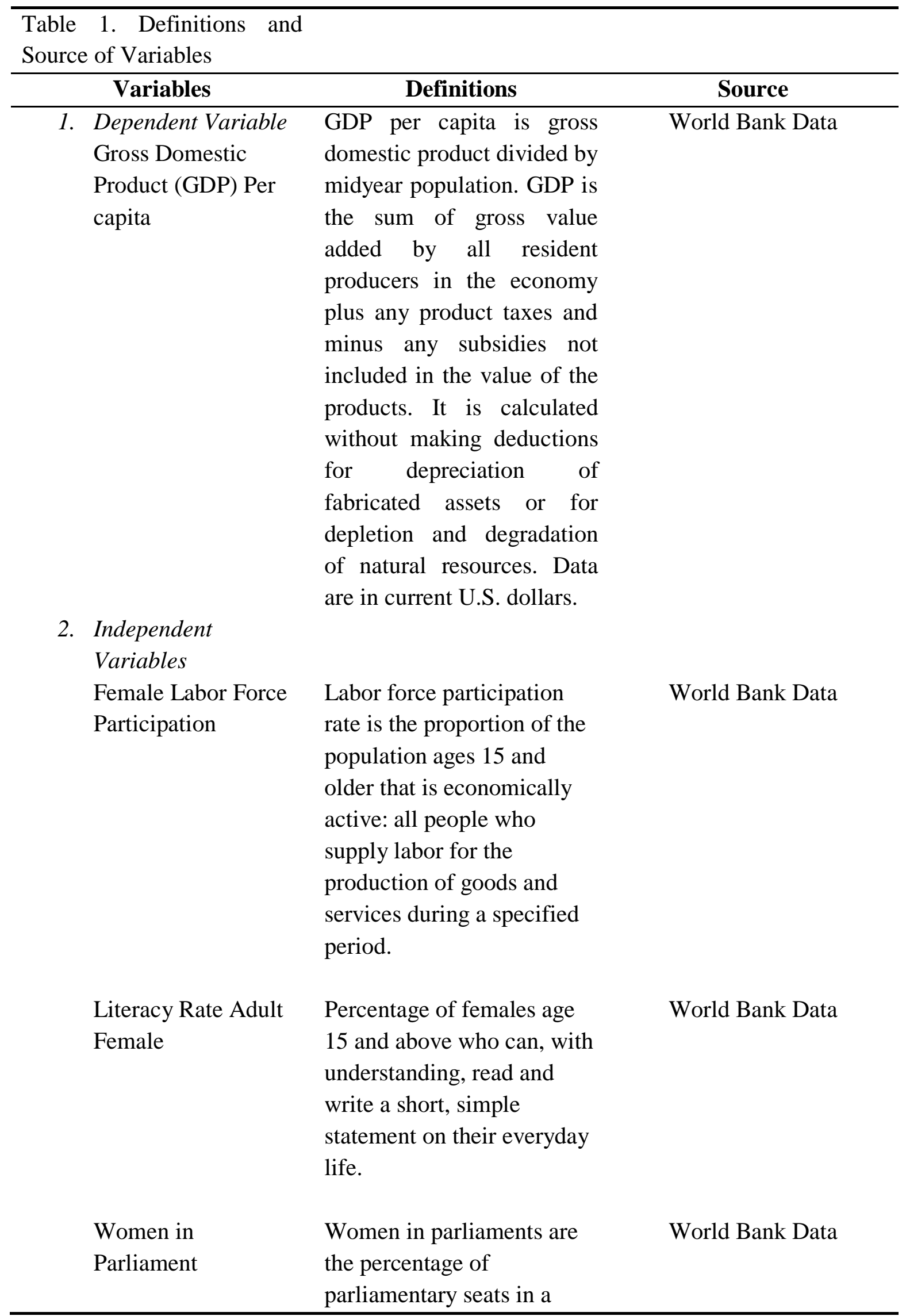


single or lower chamber

held by women.

Female

Percentage of labor force

World Bank Data

Unemployment Rate

\section{Independent Sample t Test}

The independent samples t test compares the means of two independent groups in order to determine whether there is a statistical evidence showed that the associated population means are significantly different. The independent samples $t$ test is a parametric test. Statistical test with independent sample t-test in this study aims to determine whether there are significant differences between female adult literacy, female labor force participation, female unemployment, and female in parliament of Muslim countries in the Middle East and non-Middle East.

\section{Panel Data Model}

The analytical method used is Multiple Regression Panel Data method. Data obtained are processed using e-views. In this study, the effects of independent variable on GDP per capita are studied using the panel data regression model which can be formulated as follows:

$$
\operatorname{lnGDP} P_{\text {it }}=\beta_{0}+\beta_{1} \ln F A L_{i t}+\beta_{2} \ln F L F_{i t}+\beta_{3} \ln F U_{i t}+\beta_{4} \ln F I P_{i t}+e_{i t}
$$

Where:

GDP $=$ Gross Domestic Product (GDP per capita)

$\mathrm{FAL}=$ Female Adult Literacy

$\mathrm{FLF}=$ Female Labor Force

$\mathrm{FU}=$ Female Unemployment

FIP $=$ Female In Parliament

\section{RESULT AND ANALYSIS}

Group Statistic

Table 2. Independent Sample t Test Result

\begin{tabular}{|l|l|l|r|}
\hline & \multicolumn{1}{|c|}{ Country } & \multicolumn{1}{|c|}{ N } & \multicolumn{1}{c|}{ Mean } \\
\hline female_adult_literacy & Middle East & 75 & 53.0667 \\
\hline & Non-Middle East & 175 & 27.3333 \\
\hline female_labour_force & Middle East & 75 & 48.8000 \\
\hline & Non-Middle East & 175 & 17.2667 \\
\hline female_unemployment & Middle East & 75 & 11.8629 \\
\hline & Non-Middle East & 175 & 7.4627 \\
\hline woman_in_parlement & Middle East & 75 & \\
\hline
\end{tabular}


Non-Middle East

175

17.0880

The summary statistics of the two samples are shown from the table above. It can be observed that the average of female adult literacy in Middle East countries is $83 \%$ higher than the average of female adult literacy in non-Middle East countries which only gain $60 \%$. This indicates that almost of female over the age of 15 years in Middle East countries largely been able to write and read in their own language. As for the nonMiddle East countries, only half of female over the age of 15 years is literate, which means that half of them could not read and write or would have not attended the primary school. This result comes from the lower female adult literacy rate in most of Africa countries. Although other non-Middle East such as countries in Asia region (Indonesia, Malaysia, and Brunei) and countries in Euro-Asia (Tajikistan, Turkmenistan, Uzbekistan, Kyrgyzstan, and south Caucasus, such as Azerbaijan, shards of the Soviet Union) still experience high female adult literacy rate.

In contrast to the average of female adult literacy, the average of female labor force participation in the Middle Eastern countries is low at only $27 \%$ compared with the nonMiddle East by $48 \%$. It means that many female in Middle East countries do not enter workforce and tend to be unemployed. Meanwhile, major countries in non-Middle East particularly in Sub-Saharan Africa countries have higher female labor force participation. Many female in Africa worked in the informal sector especially in agriculture.

As cause of many female in Middle East countries do not allow to enter the workforce, it then created the high average of unemployment female rate in the Middle East. Although the average is $17 \%$, the score is higher when compared to countries outside the Middle East countries which only around of $11 \%$. Furthermore, the findings also showed that between female in Muslim countries in Middle East and non-Middle East also still have gaps in politic participation. The average woman in parliament in the Middle East countries is significantly lower at $7 \%$ than in the non-Middle East at $17 \%$. It indicates that if there are 100 seats for women in parliament then only 7 women in each of Middle East countries to be the parliamentary while in non-Middle East countries is more higher to about 17 women.

\section{Independent Sample t Test}

Female Adult Literacy

The test $\mathrm{F}$ of female adult literacy with equal variance assumed is 67.6 with a probability of 0.000 . Because the probability is $<0.05$, it can be concluded that between the two variances (Middle East countries and non-Middle East countries) are significantly different or it means that the female adult literacy in the countries of Middle East and the non-Middle East has a significant difference. Meanwhile, test $t$ for the female adult literacy show that the two averages adult female participation between Middle East countries and non-Middle East countries are completely different.

\section{Female Labor Force Participation}


As for female labor force participation, both test $\mathrm{F}$ and test $\mathrm{t}$ also show that between the two variance and two averages have significant difference. Test $F$ of female adult literacy with equal variance assumed is 19.3 with a probability of 0.000 . Because the probability is $<0.05$, it can be concluded that the female labor force participation in the countries of Middle East and the non-Middle East has a significant difference. Meanwhile, test $t$ for the female labor force participation show that the two averages between Middle East countries and non-Middle East countries are completely different.

\section{Female Unemployment}

The result of test $\mathrm{F}$ and test $\mathrm{t}$ for female unemployment also show that between the two variance and two averages have significant difference. Test $F$ of female unemployment with equal variance assumed is 2.4 with a probability of 0.000 (lower than 0.05). So, it can be concluded that the female unemployment in Middle East countries and the non-Middle East countries has a significant difference. In addition, the result of test $\mathrm{t}$ is 3.8 with probability of 0.000 (or lower than 0.025 ) and it can be concluded that the average between female unemployment in Middle East countries and non-Middle East countries are completely different.

\section{Female in Parliament}

The calculation of test $\mathrm{F}$ for female in parliament also indicate that between two variance has a significant difference. Test $\mathrm{F}$ of female in parliament with equal variance assumed is 1.00 with a probability of 0.000 (lower than 0.05). Meanwhile, the calculation of $t$ test is -8.41 with probability 0.000 (or lower than 0.0025 ). So, it found that the average between female in parliament in Middle East countries and non-Middle East countries are completely different.

\section{Interpretation model and Analysis Panel Data Regression}

In this study, the regression results are provided by the construction of the RE model. Based on the data processing, the model obtained from the estimation equation as follows:

\section{$\operatorname{lnGDP}=-2.206128+1.941729 \ln F A L+0.036796 \ln F L F+0.129108 \ln F U+0.007038$ FIP}

From the equation above, it can be concluded that:

1. If female adult literacy rate in muslim countries increases by $1 \%$ and the value of other variables constant, then there will be an increase in GDP by $1,94 \%$.

2. If female labor force in muslim countries increases by $1 \%$ and the value of other variables constant, then there will be an increase in GDP by $0,04 \%$.

3. If female unemployment rate in muslim countries increases by $1 \%$ and the value of other variables constant, then there will be an increase in GDP by $0,13 \%$.

4. If woman in parliament rate in muslim countries increases by $1 \%$ and the value of other variables constant, then there will be an increase in GDP by $0,007 \%$. 
Variable GDP and Female Adult (15+) Literacy

By looking at the aforementioned equation, it can be seen that there is a positive relationship between GDP and Female Adult Literacy. This means that if female adult literacy rate increases, then there will be an increase in GDP. In addition, t-statistic value and probability value also show a significant effect of female adult literacy to the GDP. From the equation, we can interpret that increasing the female adult literacy rate to $1 \%$ will lead to an increase of GDP by around $1,94 \%$. This is consistent with a number of studies that have been done ever before that the level of education of women is giving a very significant effect on economic growth of a country.

Many scholars have studied this relation between female education and economic growth. Many of these studies match the general conclusion that economic growth benefits from the development of female education. The effects of gender gaps in education on economic growth arise primarily from the impact of female education on fertility and on the creation of human capital for the next generation (Jinyoung, JongWha, and Kwanho, 2016). As state by Xu (2015) that female education influences economic growth by three mechanisms. The first is by improving human capital. If more female allowed entering school, then more female will be educated and qualified. Thus, more educated female will lead to an improvement of human capital and this positively will affect the economic growth. The second is if more female have a better education then it will reduce the fertility rate and promote better education for next generation. In other words, the more female educated, the more next generation will be saved. And this have a big impact for economic growth. The last mechanism is related with income. Female with better education will have a better job and gain more income than female paid less. This is also positively affects the economic growth.

\section{Variable GDP and Female Labor Force Participation}

Based on the aforementioned equation, it can be concluded that a positive relationship can be observed between GDP and Female Labor Force Participation. Unfortunately, as we can see that t-statistic value and probability value appear to show an insignificant effect. This indicates that GDP is not influenced by the female labor force participation despite having positive relationship. Probably, the influence does not appear in a short time. The study that conducted by Shahid (2014) also found that there is no relationship between economic growth and female labor participation in short run. His study used time period of 1980 to 2012, which is collected from Pakistan Bureau of Statistics, World Bank and State Bank of Pakistan. He then found that by using the Johnson Co-integration test, the long run relationship exist between economic growth and female labor force participation. However, the vector error correction model indicated the disequilibrium of variables. He concluded that economic growth showing convergence, gross fixed capital formation showing divergence and labor force participation also showing convergence in short run. 
A number of studies that have been done showed that the effect of female labor force participation to economic growth forming a U-shape relationship in the long term. Goldin 1994; Tansel (2002), Fatima and Sultana (2009), Kottis (1990), and Lechman and Kaur (1999) proved that economic development and women labor force have shown a Ushaped relationship. The U-shape indicates that there is a negative and positive relationship between economic growth and female labor force. However, the strong effect of negative and positive according to Lechman and Kaur (1999) varied across the countries.

\section{Variable GDP and Female Unemployment}

As we can see from the aforementioned equation, the relationship between GDP and female unemployment is positive but also insignificant. The value of t-statistic and probability show that GDP is not significantly affected by female unemployment. It seems that the relationship also does not appear in the short term as well as the findings in female labor force participation above. This is also can be explained that unemployment rate does not affect economic growth directly but firstly affect female labor force participation. Unemployment tends to discourage workers to find job. As Tansel (2002) point outs, the effect of the unemployment on labor force participation relies on the relative strengths of discouraged worker effect and the added worker effect. If an increase in unemployment rates results in lower labor-force participation rate, this signals the existence of discouraged worker effect. As a result, if unemployment rate is high, then it will lower the rate of labor force participation. If the labor force participation is lower, then it will negatively affect the economic growth.

Furthermore, related to the existence of discourage/added worker effect on unemployment rate, Ozerkek (2013) found that in the long-run relationship the discourage worker effect only exists in females. The findings also suggest that an increase in the unemployment rate brings about "hidden unemployment," for females.

\section{Variable GDP and Female in Parliament}

Meanwhile, women participation in parliament interestingly showed a positive and significant affect to GDP. The higher of woman in paliament, the higher of economic growth rate in Muslim countries. It can be interpreted from the aforementioned equation that if female in parliament rate increase 1\%, it will increase the GDP per capita of each country as much as 0.007 percent. This is also equal with a number of studies which investigated to examine the influence of female in parliament with economic development. $\mathrm{Xu}$ (2015) states that one of the advantages of female politics is that women are less corrupt than men. Female's behavior is always different from male according to practical experiments.

\section{CONCLUSION}

The main objective of this study is to determine whether there are significant differences between female participation of Muslim countries in Middle East and non- 
Middle East. Furthermore, this study also try to examine the impact of female empowerment on economic growth in Muslim countries. In order to express female's role and participation, this study use some explanatory variable, that is female labor force participation rate $(\%)$, female participation in parliament $(\%)$, female unemployment rate $(\%)$ and female literacy rate $(\%)$.

The result of this study finds that there are significants differences between female participation in Middle East countries and non-Middle East countries. Female literacy rate in the Middle East countries higher than non-Middle East countries although their female unemployment result also tend to be higher. While for the female labor force participation and female in parliament in Middle East countries is lower than non-Middle East countries. Both female adult literacy rate and female participation in parliament have a positive and significant relationship with economic growth in largest Muslim population countries. Hence, the results suggest that primary education and literacy programs are very important not only to improve the ability and quality of female but also it can develop the economy of a country.

As well as female literacy rate, the positive and significant effect on economic growth also appears in female participation in parliament. The interpretation from the estimate model suggests that the more female seat in parliament or the more female become policy maker, the more economic will grow. The latest research conducted by $\mathrm{Xu}$ (2015) also found the same thing. $\mathrm{Xu}$ states that one of the advantages of female politics is that women are less corrupt than men. Female's behavior is always different from male according to practical experiments.

Meanwhile, the result of female labor force participation and female unemployment rate show insignificant effect on economic growth. The explanation of this evidence is that the regression is done only for a short period of 5 years. Some research has been done showing that both female labor force participation and female unemployment has significance on a long-term relationship. In addition, female unemployment is not able to demonstrate direct relation with economic growth, because the female unemployment directly affect on female labor force participation. Where, if female unemployment is higher, the female labor force participation will be low. And if female labor force participation is low, it will have a negative effect on economic growth. Discourage worker effect is agreed to be the main cause of unemployment.

However, the female inequality in education, workforce, and politics still experienced until today. The latest data from the World Bank show that both female literacy rate and female participation in parliaments tend to be lower than male. Female labor force participation and female unemployment rate also show inequality between female and male. Some factors may be the caused this inequality problem, such as culture of the society and government policy. Therefore, reformation should be made for a renewal to pursue the underdevelopment in Islamic world. Moreover, Islam as a religion professed by Muslim countries does not prohibit and restrict the role and participation of women in society and for economic development. Islam teaches equality between women and men. Historically, some of Muslim women figure also contributed to economic development. 
They act as a trader such as Khadijah R.A, they also learned, well-educated and smart such as Aisha R.A, they become a nurse such as Rufaida binti sa'ad, and many other professional such as politician, teacher, entrepreneur, doctor, scientist, and even farmer. Female still can contribute to society without abandoning their duties and responsibilities as a wife and a mother.

\section{REFERENCE}

Kuran, T 1997, 'Islam and Underdevelopment: An Old PuzzleRevisited', Journal of Institutional and Theoretical Economics (JITE), vol. 153, no.1, pp.41.

Ebrahim, MS, Makhdoomi, S, \& Sheikh, M 2012, 'The Political Economy and The Parennial Underdevelopment of The Muslim World', Bangor Business School Bangor University, October 2012, p. 2.

Ahmad, N, Bhatti, KA, \& Arshad, MU 2013, 'Economic Growth and Human Development in Islam', Al-Qalam, December 2013, p. 74.

Lewis, B 2002, 'What Went Wrong? Western Impact and Middle Eastern Response', Oxford University Press, p. 151.

Jinyoung, K, Jong-Wha, L, \& Shin, K 2016, 'A Model of Gender Inequality and Economic Growth', Asian Development Bank Economics Working Paper Series, February 2016, no. 475, p. 1-35.

Dollar, D \& Gatti, R 1999, 'Gender Inequality, Income, and Growth: Are Good Times Good for Women?', Washington, DC: Development Research Group, The World Bank, vol. 1.

Al Khayat, M 2003, 'Woman in Islam and her Role in Human Development', World Health Organization - Community Based Initiatives Series, no.22, p. 1-30.

Huda, N 2012, 'Keuangan Publik Islami Pendekatan Teoretis dan Sejarah', Kencana Prenada Media Group, p. 178.

Noland, M 2003, 'Religion, Culture, and Economic Performance', KDI School Working Paper Series, 20 November 2003, p. 43.

Chapra, UM 2006, 'Ibn Khaldun's Theory of Development: Does It Help Explain The Low Performance of The Present-Day Muslim World?', Islamic Research and Training Institution - Islamic Development Bank, p. 12 - 14.

Genc, IH, AbuAl-Foul, BM, \& Ozkul, L 2012, 'Women's Role In Economic Development In Predominantly Muslim Countries', Journal of Islamic Economics, Banking and Finance, vol.8, no.3, July - September 2012, p. 3.

'Increasing Rural Employment in Sub-Saharan Africa', 2012, CTA Policy Brief, 4 February, p. 3.

Moghadam, VM 2005, 'Wome's Economic Participation in the Middle East: What Difference Has the Neoliberal Policy Turn Made?', Journal of Middle East Women's Studies, vol.1, no.1, p. 110-146.

Johannes, E 2010, 'Women's Education in Sub-Saharan Africa: Obstacle Facing Women and Girls Access to Education: The Case of Kenya, Kenya Studies Review, 2 December, vol.1, no.2, p. 1-16. 
Jelili, RB 2010, 'The Arab Region's Unemployment Problem Revisited', The Arab Planning Institute, p. 8.

Sayre, E, Benmansour, NA, \& Constant, S 2015, 'The Determinants of Youth Unemployment in Qatar', Topics in Middle Eastern and African Economies, vol17, no.2, May 2015, p. 17.

Ndlovu, S \& Mutale, SB 2013, 'Emerging Trends in Women's Participation in Politics in Africa', American International Journal of Contemporary, vol.3, no.11, p. 3.

Oztunc, H, Oo,ZC, \& Serin, ZV 2015, 'Effect of Female Education on Economic Growth: A Cross Country Empirical Study', Educational Sciences:Theory and Practice, April 2015, vol. 15(2), p. 349 - 357.

Lamana, F and Klasen, S 2009, 'The Impact of Gender Inequality in Education and Employment on Economic Growth: New Evidence for A Panel of Countries', Feminist Economics, vol.15(3), July 2009, p. 91 - 132.

Lechman, E \& Kaur, H 2015, 'Economic Growth and Female Labor Force Participation Verifying the U-Feminization Hypothesis. New Evidence for 162 Countries Over the Period 1990-2012', Economics and Sociology, vol. 8, no 1, p. $246-257$.

Jayasuriya, D \& Burke, PJ 2012, 'Female Parliaments and Economic Growth: Evidence From A Large Panel', Development Policy Centre Crawford School of Public Policy ANU College of Asia and The Pacific, May 2012, p. 1 - 8.

$\mathrm{Xu}, \mathrm{L} 22015$, 'Effects of Female Political Participation on Economic Growth: Evidence From Asian Countries' Master Thesis, Lund University.

Nachrowi, ND \& Usman, H 2008, Penggunaan Teknik Ekonometri,Edisi Revisi, PT. Raja Grafindo Persada, Jakarta.

Lahoti, R \& Swaminathan, H 2013, 'Economic Growth and Female Labor Force Participation in India, Working Paper of Indian Institute of Management Banglore, no.414, June 2013, p. 1 - 42.

Shahid, M 2014, 'Impact of Labor Force Participation on Economic Growth in Pakistan', Journal of Economic and Sustainable Development, vol. 5, no.11, p. 1 - 6.

'Women in Parliament: 20 Years in Review', 2015, Inter-Parliamentary Union (IPU), p.4.

Kottis, AP 1990, 'Shifts Over Time and Regional Variation in Women's Labor Force Participation Rates in A Developing Economy', Journal of Development Economics, p.117-132.

Tansel, A 2002, 'Economic Development and Female Labor Force Participation in Turkey: Time-Series Evidence and Cross-Province Estimates', ERC Working Papers in Economics, 01/05T.

Ozerkek, Y 2013, 'Unemployment and Labor Force Participation: A Panel Cointegration Analysis For European Countries', Applied Economics ad International Development, vol.13, no.1, p.1-10.

Al Tal'ei, R 2007, 'Where are Female in Middle East Countries Politics?', Common Ground News Article, www.commongroundnews.org 
OIKONOMIKA: Jurnal kajian Ekonomi dan Keuangan Syariah Volume 1 Nomor 2, Desember 2020

Kelly, S, 'Recent Gains And New Opportunities For Women's Rights In The Gulf Arab States', Women's Rights in The Middle East and North Africa, Overview Essay - Gulf Edition, Freedom House.org 